\title{
Lateness: A Recurrent Problem among Secondary School Students in Akoko South East Local Government Area of Ondo State Nigeria, Implications for Counselling
}

\author{
Anna Onoyase ${ }^{1}$ \\ ${ }^{1}$ Department of Guidance and Counselling, Delta State University, Abraka, Nigeria \\ Correspondence: Anna Onoyase, Department of Guidance and Counselling, Delta State University, Abraka, \\ Nigeria. Tel: 8-035-79-9712. E-mail: anna_onoyase@yahoo.com
}

Received: December 15, 2016

Accepted: December 19, 2016

Online Published: February 22, 2017

doi: $10.5539 /$ hes.v7n $1 \mathrm{p} 107$

URL: http://doi.org/10.5539/hes.v7n1p107

\begin{abstract}
The study investigated lateness as a recurrent problem among secondary school students in Akoko South East Local Government Area of Ondo State. Four hypotheses were formulated and an instrument titled "Cause of Lateness to School Questionnaire" (COLTSQ) used to gather data for the study. The instrument had a reliability coefficient of 0.78 . It had content validity and language appropriateness. The researcher used two research assistants to administer 325 copies of the questionnaire on SS2 and SS3 students in the 5 public secondary schools used. 300 copies of the questionnaire were retrieved showing 92.3 percent return rate. The data collected were collated and the t-test statistics was used to test the hypotheses at 0.05 level of significance. The findings showed that there is no significant difference between male and female students in their identification of electronic media as a reason for lateness to school, there is no significant difference between students from high and low socio-economic status in their identification of broken home as a reason for lateness to school, there is no significant difference between SS2 and SS3 students in their identification of location of school as a reason for lateness to school, there is no significant difference between students in urban and rural areas in their identification of cultural background as a reason for lateness to school. One of the recommendations is that parents should put in place enforceable rules or time limit for watching television programmes at night and ensure that their children go to bed early.
\end{abstract}

Keywords: lateness, high socio-economic status, low socio-economic status, urban and rural students

\section{Introduction}

Over the years, lateness to school by students of secondary schools has become a recurrent issue. Probably, this was why Chujor (2014) stressed that school administrators, teachers, parents and others have shown sincere concern about it. Chujor asserted that a lot of measures have been adopted to curb the occurrence such as giving punishment like flogging or being sanctioned. In short, recurrent lateness to school by students may be one of the reasons responsible for the falling standards of education in Nigeria. If lateness to school is allowed to continue, it may have adverse effect on the attainment of the objectives of the Universal Basic Education (UBE). The Federal Government of Nigeria maintained that the UBE programme was geared towards achieving the following objectives:

1) Developing in the general citizenry a strong consciousness for education and strong commitment to its vigorous promotion.

2) The provision of free universal basic education for every Nigerian child of school-going age.

3) Reducing drastically the incidence of dropout from formal school system through improved relevance quality and efficiency.

Without doubt, for any school to succeed in discharging its basic duty of training students, there should be some form of discipline. This according to Salifu and Agbenyega (2012) is necessary because it sets a congenial atmosphere needed for teaching and learning. Discipline encompasses punctuality and regularity of students in school. It is only when learners are present in school and at the right time, that they can benefit optimally from the academic programme. Jumare, Maina and Ankoma-Sey (2015) opined that when students are punctual to 
school, they are opportuned to attend to all school programmes and activities and most importantly, get full benefits of morning hour lessons such as English Language and Mathematics. The authors further noted that latecomers are flogged and given other punishment (such as toilet washing, sweeping and weeding) which make them experience pains and thus are unable to participate in morning classes.

Van-Breda (2006) stressed that recurrent lateness to school may not only affect the academic performance of students, it could also create serious problems for such individuals in later life if not checked. However, Chujor (2014) asserted that lateness to school can be excused in some cases when the reasons are cogent and beyond the student's control. Manguvo, Whitney and Chareka (2011), observed that there has been a high prevalence of indiscipline among learners at all levels of the Nigerian educational system and that the most common students' behaviour problems include stealing, not doing homework and lateness.

\subsection{Probable Causes of Lateness}

Some of the likely causes of lateness in secondary schools include the mass media, broken homes, cultural background, too much body care, location of school, and socio-economic status of parents. In the study, four of these factors will be discussed.

\subsection{Mass Media}

This research will lay emphasis on the electronic media; specifically cable television, cell phone, tablets, laptops and MP3 players. From observation, some students download movies into their cell phones and watch them late in the night. Again, some others, listen to MP3 players for a long time at night. It is common knowledge that when individuals go late to bed, they will also wake up late. Kubiszewki, Fontaine, Rusch and Hazouard (2012) undertook a study on Association between electronic media use and sleep habits. The participants were 332 adolescents from 5 middle schools in the city of Tours (France) and its suburbs and the results revealed that availability and use of electronic media such as cell phones and MP3 players in the bedroom make students to go late to bed and consequently experience difficulty in waking up early. Definitely, inadequate sleep might slow down students' rate of preparation for school and eventually arrive late.

Ubogu (2004) pointed out that some students who have formed the habit of watching late night movies and home videos usually sleep late. Continuing, he reiterated that these individuals may be so captivated and hypnotized that they forget they have to be in school the next day. Consequently, they wake up late and become late arrivals at school. Sarkodie, Ntow-Gyan, Bempong and Saka (2014) in their study of Assessment of Absenteeism and Lateness among Hospitality and Tourism students in Sunyani Polytechnic, Ghana, found out that majority of students strongly disagreed that going late to bed caused lateness to school among students.

\subsection{Broken Homes}

Broken homes resulting from separation, divorce, dissertation or death of parents maybe a factor in students' late arrival at school. Omozeghian (2007) and Onoyase (2013) describe a broken home as a home where the marriage between a man and a woman has hit the rock and the couple now stay separately. They maintained that children of such a marriage now move between their father and mother in their separate homes and that most of these students have been found to go late to school and thus perform poorly academically.

Observation has revealed that products of this type of home suffer much neglect (in terms of food and school materials) with one parent shifting responsibility to the other and pointing accusing fingers at themselves for the plight of their children.

\subsection{Cultural Background}

In the African society (specifically, the Nigerian society), punctuality is not perceived as an important virtue. This perception seems to pervade all segments of the country. Commenting on this, Breezes, Markey and Woll (2010) emphasized that we live in a society where the culture does not frown at lateness. They further stated that punctuality is not seen as a serious issue compared with how it is perceived in the Western world.

Thus, many students have not regarded punctuality as a habit to cultivate. Lyamba (2013) conducted a research on the Relationship between Home Environment and Indiscipline among Pupils in Selected Primary Schools in Mongu District, Zambia. The sample were 80 pupils, 16 teachers, 20 parents and 8 head teachers and their deputies and the results indicated that community influence and the media were some of the causes of indiscipline.

\subsection{Location of School}

Oghuvwu (2008) noted that distance to school is one of the causes of lateness of our secondary school students. Dafiaghor (2011) not only agreed that distance to school results to lateness but distractions like hold-ups, or 
go-slows is also responsible. Sarkodie, Ntow-Gyan, Bempong and Saka (2014) in their study found out that large proportion of students agreed that lateness to school is caused by long distance between the school and their residences.

Recurrent lateness to school: This means persistent. Lateness to school.

High socio-economic status is used to mean educational qualification of parents up to a university degree or its equivalent with adequate income as a result of their occupation.

Low-socio-economic status is used to mean educational qualification of parents below a university degree with income equivalent to their occupation.

Senior Secondary School One Students (SS 1) refer to students who are in their first year of the senior secondary school.

Senior Secondary School Two Students (SS 2) refer to students who are in the second year of the senior secondary school.

Senior Secondary School Three students (SS 3) refer to students who are in their third year of the senior secondary school.

Urban Students: These are students whose secondary schools are located in towns with electricity, pipe borne water, water system toilet and motorable roads.

Rural Students: These are learners whose schools are situated in villages where there are no electricity, pipe borne water and motorable roads.

\subsection{Statement of the Problem}

The issue of lateness is not a new phenomenon in Nigerian public secondary schools. The rate of lateness which was low in the past has increased tremendously and efforts by various school authorities to address this problem seem not to have yielded the desired result. It is now a common feature to see students walking leisurely to school after the resumption time (between 7.45am-8.00am) and consequently miss the first/second lessons of the day. What appears to be more worrisome is students' attitude to lateness, which they have come to embrace as a "normal aspect" of our culture. Worse still, when these late arrivals get to their various classes after serving one form of punishment or the other, they not only distract the attention of teachers but also that of their classmates. This negative behaviour if unchecked might truncate the achievement of the stated educational goals. The problem of this study therefore, is to investigate the issue of recurrent lateness among secondary school students in Akoko East Local Government Area of Ondo State with a view to proffering effective techniques of minimizing lateness through counselling.

\section{Hypotheses}

The researcher formulated four hypotheses to guide the study:

1) There is no significant difference between male and female students in their identification of electronic media as a reason for lateness to school.

2) There is no significant difference between students from high and low socio-economic status in their identification of broken home as a reason for lateness to school.

3) There is no significant difference between Senior Secondary two (SS 2) and Senior Secondary three (SS 3) students in their identification of location of school as a reason for lateness to school.

4) There is no significant difference between urban and rural students in their identification of cultural background as a reason for lateness to school.

\section{Research Procedure and Methodology}

The study adopted Ex-post Facto design using descriptive method. Asika (2004, p. 24) maintained that Ex-post Facto research is a systematic empirical study in which the researcher does not manipulate or control independent variables because the situation for the study has already taken place.

There were 8 public secondary schools in Akoko South East Local Government Area of Ondo State at the time the research was carried out. The investigator used the random sampling technique to select 5 out of 8 public secondary schools that participated in the study. The 5 secondary schools constituted 62.5 percent of the total number of secondary schools.

The researcher made use of an instrument known as the "Causes of Lateness to School Questionnaire" (COLTSQ) to collect data for the study. It had 20 items, the Likert 4 point scale of Strongly Agree (SA), Agree 
(A), Disagree (D), and Strongly Disagree (SD) were used and scored as 4, 3, 2 and 1 respectively for positive items and reverse order for negative items. The COLTSQ had a reliability coefficient of 0.78 . It also had content validity and language appropriateness.

The researcher used 2 research Assistants to administer 325 copies of the questionnaire on Senior Secondary Two (SS 2) and Senior Secondary Three (SS 3) students in the 5 public secondary schools used for the study. 300 copies of the questionnaire were retrieved showing 92.3 percent return rate. The data collected from the field were collated and the t-test statistics was used to test the hypotheses at 0.05 level of significance.

\section{Findings}

\subsection{Hypothesis One}

There is no significant difference between male and female students in their identification of electronic media as a reason for lateness to school.

Table 1. T-test analysis of difference between male and female students in their identification of Electronic Media as a reason for lateness to school

\begin{tabular}{ccccccc}
\hline Group & N & df & Mean & t-calculated & t-critical & Remark \\
\hline Male Students & 175 & 298 & 34.18 & 1.10 & 1.96 & Not Significant \\
Female Students & 125 & & 33.52 & & & \\
\hline
\end{tabular}

Source: Fieldwork, 2016.

Table one shows mean of 34.18 for male students and 33.52 for female students. It shows the t-calculated to be 1.10 while $t$-critical, 1.96. Since the value of $t$-critical is higher than $t$-calculated at 0.05 level of significance, the hypothesis which says that there is no significant difference between male and female students in their identification of electronic media as a reason for lateness to school is retained.

\subsection{Hypothesis Two}

There is no significant difference between students from high and low socio-economic status in their identification of broken home as a reason for lateness to school.

Table 2. T-test analysis of difference between students from high and low socio-economic status in their identification of broken home as a reason for lateness to school

\begin{tabular}{lcccccc}
\hline Group & N & df & Mean & t-calculated & t-critical & Remark \\
\hline Students of low socio-economic status & 205 & 298 & 33.83 & \multirow{2}{*}{0.61} & 1.96 & Not Significant \\
Students of high socio-economic status & 95 & & 33.57 & & & \\
\hline
\end{tabular}

Source: Fieldwork, 2016.

The mean for students from low socio-economic status is 33.83 while that of students from high socio-economic status is 33.57. Since both means did not show a significant difference at 0.05 level of significance, the hypothesis which says that there is no significant difference between students from high and low socio-economic status in their identification of broken home as a reason for lateness to school is upheld.

\subsection{Hypothesis Three}

There is no significant difference between SS 2 and SS 3 students in their identification of location of school as a reason for lateness to school. 
Table 3. T-test analysis of difference between SS2 and SS3 students in their identification of location of school as a reason for lateness to school

\begin{tabular}{ccccccc}
\hline Group & N & df & Mean & t-calculated & t-critical & Remark \\
\hline SS2 students & 186 & 298 & 34.16 & 1.45 & 1.96 & Not Significant \\
SS3 students & 114 & & 33.43 & & & \\
\hline
\end{tabular}

Source: Fieldwork, 2016.

Table three shows a mean of 34.16 for SS2 students and 33.43 for SS3 students. The value of t-calculated is 1.45 while that of t-critical is 1.96. Since the value of t-critical is higher than that of $t$-calculated at 0.05 level of significance, the hypothesis which says that there is no significant difference between SS2 and SS3 students in their identification of location of school as a reason for lateness to school is retained.

\subsection{Hypothesis Four}

There is no significant difference between urban and rural students in their identification of cultural background as a reason for lateness to school.

Table 4. T-test analysis of difference between urban and rural students in their identification of cultural background as a reason for lateness to school

\begin{tabular}{ccccccc}
\hline Group & N & df & Mean & t-calculated & t-critical & Remark \\
\hline Urban students & 229 & 298 & 33.74 & 1.78 & 1.96 & Not Significant \\
Rural students & 71 & & 34.77 & & & \\
\hline
\end{tabular}

Source: Fieldwork, 2016.

Table four shows a mean of 33.74 for urban students and a mean of 34.77 for rural students. Since both means did not show a significant difference at 0.05 level of significance, the hypothesis that says that there is no significant difference between students from urban and rural area in their identification of cultural background as a reason for lateness to school is upheld.

\section{Discussion}

One of the findings of this investigation indicated that there is no significant difference between male and female students in their identification of electronic media as a reason for lateness to school. This implies that boys and girls alike have identified the use of the cell phone, cable television and MP3 players as a reason for lateness to school. This finding contradicts that of Sakodie, Ntow-Gyan, Bempong and Saka (2014) who found out that majority of students strongly disagreed that going to bed late caused lateness to school among students. However, this finding agrees with Ubogu (2004) who maintained that the individuals involved in watching late films and home videos may be so captivated and hypnotized by them that they forget they have to be in school the next day and likely may not be punctual in class.

Also, the result of this research corroborates the study of Kubiszewki, Fontaine, Rusch and Hazourd (2012) who discovered that the availability and use of cell phones and MP3 players in the bedroom make students go late to bed and rise up late as well.

Another finding of the investigation revealed that there is no significant difference between students from high and low socio-economic status in their identification of broken home as a reason for lateness to school. Irrespective of the socio-economic status which the students come from, they have all identified broken home as a reason for lateness to school. This may be so because children are not properly supervised in such homes. This finding supports Omozeghian (2007) and Onoyase (2013) who maintained that one of the characteristics of students in a broken home is that most of them are found to go to school late and therefore perform poorly in academics.

Thirdly, another finding of this research has shown that there is no significant difference between SS 2 and SS 3 students in their identification of location of school as a reason for lateness to school. Students from both classes (SS 2 and SS 3) have agreed that location of school is a reason for lateness. This finding lends credence to the 
study of Sarkodie, Ntow-Gyan, Bempong and Saka who found out that large proportion of students agreed that lateness to school is caused by long distance between the school and their residences.

Finally, the study found out that there is no significant difference between students from urban and rural areas in their identification of cultural background as a reason for lateness to school. The opinions of urban and rural students appear to be similar in identifying cultural background as a factor responsible for lateness to school. This finding supports Breezes, Markey and Woll (2010) who opined that cultural background is a cause of lateness to school. They observed, that for most individuals, punctuality is not really a serious matter in our African society, compared to how it is perceived in the Western world. This result is in line with the work of Lyamba (2013) which revealed the media and community as some of the causes of indiscipline (lateness).

\section{Conclusion}

The conclusion that can be drawn from the findings is that the problem of lateness to school is still common among secondary school students of Akoko East Local Government Area of Ondo State.

\section{Recommendations}

The following recommendations have been made:

1) Parents should put in place enforceable rules on time limit for the use of cable television, cell phones and MP3 players at night and ensure that their children go to bed early.

2) The Federal government should enact laws that ban school children from hawking so that they can prepare for school on time.

3) The state government, local government as well as non-governmental organizations should give scholarships to students from low socio-economic status homes to alleviate the financial burden of their parents.

4) Marriage counsellors should organize pre-marital counselling for the general public on the need for courtship before marriage so that would-be couples can adjust to their marriage and thereby minimize the incidence of divorce.

5) School administrators should give prizes to students who are always punctual to school so as to motivate other students.

6) Teachers should act as good models to their students by being punctual to school and to classes.

\section{Counselling Implications}

Some of the counselling implications are:

1) Counsellors are needed in secondary schools to organize seminars on time-management skills so that students can utilize their time effectively and perform optimally in their studies.

2) Through the use of Rational Emotive Behavioural Therapy (REBT), counsellors are to help students to change their irrational beliefs of "African time" (copied from their parents) and imbibe the culture of punctuality.

3) Counsellors should counsel parents of students who are "chronic latecomers" to encourage their children to be punctual to school.

4) The Counselling Association of Nigeria (CASSON), Ondo State chapter should organize workshops and seminars for parents and the general public in order to change their wrong beliefs about lateness.

\section{References}

Breezes, S., Markey, C., \& Woll, V. (2010). "How to be Punctual" WikiHow: The how to manual that you can edit. Retrieved September 23, 2010, from http://www.wikihow.com/Be-Punctual

Chujor, J. C. (2014). Effects of Counselling in Curbing Persistent Lateness to school among University Secondary Students in River State, Nigeria. Retrieved from http://www.ijird.com

Dafiaghor, K. E. (2011). Lateness: A major problem confronting school administrators in Delta State. Nigeria International NGO Journal. Retrieved from http://www.academic journal.org/NGOJ

Federal Republic of Nigeria. (2004). National Policy on Education. Lagos NERDC.

Jumare, M. A., Maina, A. B., \& Ankoma-sey, R. V. (2015). Analysis on Students' Late-coming Factors in Selected Secondary Schools in zaria: Implications for Educational Managers. Journal of Education and Practice, 6(32), 55-61. 
Kubiszewski, V., Fontaine, R., Rusch, E., \& Hazouard, E. (2014). Association between Electronic Media Use and Sleep Habits: An eight-day follow-up study. International Journal of Adolescence \& Youth, 19(3), 395-407. https://doi.org/10.1080/02673843.2012.751039

Lyamba, B. (2013). The Relationship between Home Environment and Indiscipline among Pupils in Selected Primary Schools in Mondu district, Zambia (Unpublished M.Ed Dissertation). University of Zambia, Lusaka.

Manguvo, A., Whitney, S. D., \& Chareka, O. (2011). The crisis of student misbehavior in Zimbabwean Public Schools: Teachers' perception on impact of Macro-socio-economic challenges. International Journal of Educational Administration and Policy Studies, 2(4), 40-44.

Oghuvwu, P. E. (2008). Absenteeism and Lateness among Secondary School Students in Nigeria: Providing causes and Solutions. Academic Leadership.

Omozeghian, G. E. (2007). Introduction to Sociology of Education. Agbor: His Glory Prints.

Onoyase, D. (2013). Sociology of Education. Warri: Jonny \& Co.

Salifu, I., \& Agbenyega, J. S. (2012). "Impact of discipline issues on school effectiveness: The views of some Ghanaian Principals", MIE Journal of Educational Studies. Trends and Practic, 2(1), 50-65.

Sarkodie, N. A., Ntow-Gyan, K., Bempong, E. K., \& Saka, G. A. (2014). Assessment of Absenteeism and Lateness among Hospitality and Tourism Students in Sunyani Polytechnic. Journal of Education and Practice.

Ubogu, R. E. (2004). The causes of absenteeism and dropout among secondary school students in Delta Central Senatorial District of Delta Sate (Unpublished Ph.D Thesis). Abraka Delta State University.

Van-Breda, M. J. (2006). Guidelines for Empowering Secondary Schools Education in Loco Parents. In Addressing Truancy among early Adolescent Learners. University of South Africa.

\section{Copyrights}

Copyright for this article is retained by the author(s), with first publication rights granted to the journal.

This is an open-access article distributed under the terms and conditions of the Creative Commons Attribution license (http://creativecommons.org/licenses/by/4.0/). 